\title{
A Case of Asymptomatic Multiple Endocrine Neoplasia Type I Detected Incidentally on Health Screening
}

\author{
Pyung-San Cho, Hoon Park, Guk-Haeng Lee and Myung-Chul Lee \\ Department of Otolarygology-Head \& Neck Surgery, Korea Cancer Center Hospital, Seoul, Korea

\section{정기 건강 검진상 우연히 발견된 무증상의 제1형 다발성 내분비선종증 1 예} \\ 조평산 · 박 훈 · 이국행 · 이명철 \\ 한국원자력의학원 원자력병원 이비인후-두경부외과학교실
}

Received January 5, 2012

Revised March 20, 2012

Accepted March 27, 2012

Address for correspondence

Myung-Chul Lee, MD

Department of Otolarygology-

Head \& Neck Surgery,

Korea Cancer Center Hospital,

75 Nowon-ro, Nowon-gu,

Seoul 139-706, Korea

Tel $+82-2-970-2173$

Fax $+82-2-970-2450$

E-mail1mc@daum.net
Multiple endocrine neoplasia type 1 (MEN 1) is characterized by the coexistence of primary hyperparathyroidism, enteropancreatic tumors, and anterior pituitary adenoma. Also adrenal adenoma, lipoma, carcinoid tumors could exist simultaneously on the atypical clinical course of MEN 1. Among these diseases, primary hyperparathyroidism is the most common manisfestation of MEN 1 syndrome. However, it sometimes presents no clinical symptoms and is incidentally detected on medical checkup. A 48-year-old woman, while undergoing a regular medical check-up, was diagnosed with primary hyperparathyroidism. Further studies showed concurrence of pancreatic tumor and adrenal tumor, but there was no pituitary lesion. The patient underwent parathyroidectomy with auto-implantation of parathyroid tissue, pylorus preserving pancreatico-duodenectomy and partial adrenalectomy. The pathological test confirmed it to be parathyroid hyperplasia, well-differentiated pancreatic endocrine carcinoma and adrenal cortical adenoma. We report this atypical and asymptomatic case of MEN 1 with a review of the relevant literature.

Korean J Otorhinolaryngol-Head Neck Surg 2012;55:373-7

Key Words Multiple endocrine neoplasia type 1 - Hyperparathyroidism · Parathyroid hyperplasia $\cdot$ Parathyroidectomy.

\section{서 론}

제1형 다발성 내분비선종증(multiple endocrine neoplasia type 1, MEN 1)은 1904년 처음 발견된 이후, 1954년 유전질 환으로 알려지기 시작하였으며,") 이후 11 번 염색체의 13 번 장 완에 위치하는 종양억제 유전자인 MEN 1의 배선 돌연변이 (germ line mutation)가 원인이 되는 것으로 밝혀졌다. MEN 1 은 부갑상선, 장-췌장 내분비선, 뇌하수체 중 2 기관 이상에 서 증식성 병변(과증식, 선종, 암종 등)이 있는 경우 진단할 수 있는데 이 외에 부신 피질 종양(adrenal cortical adenoma), 지 방종(lipoma), 갈색 세포종(pheochromocytoma), 갑상선 선 종(thyroid adenoma), 유암종(carcinoid tumor) 등이 있는 경 우에는 비전형적 MEN 1으로 진단할 수 있다. ${ }^{2)}$ 보통 상염색체 우성으로 유전되지만 가족력이 있는 경우보다 산발적으로 발
생하는 경우가 많으며, 산발적인 경우에도 약 $20 \%$ 가량에서는 유전자 돌연변이가 검출된다. MEN 1 의 가장 흔한 임상 양상 은 부갑상선기능항진증이며 이는 평균적으로 20대에서 발현 되는데 50 세 이상에서는 거의 $100 \%$ 에서 발현한다. ${ }^{1,3)}$

저자들은 건강 검진의 갑상선 초음파에서 우연히 부갑상 선의 종물이 발견되어, 추가적으로 시행한 검사상 부갑상선 외 에도, 췌장, 담낭, 부신, 뇌하수체의 병변을 발견해 수술적 치료 를 시행한 비전형적이고 무증상의 $\mathrm{MEN} 1$ 증례를 경험하였 기에 문헌 고찰과 함께 보고하는 바이다.

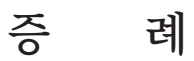

건강 검진에서 발견된 경부의 종물로 내원한 48세 여자 환자 로 타 병원에서 시행한 건강 검진의 경부 초음파에서 갑상선의 
결절이 발견되어 시행한 세침흡인 세포진 검사(fine needle aspiration cytology, FNAC)에 결과 갑상선의 병변이 의심된다 하여 향후 치료를 위해 본원에 내원하였다. 본원에서 시행한 병리 슬라이드 판독상 부갑상선 조직이 확인되었고, 본원에 서 다시 시행한 $\mathrm{FN} \mathrm{AC}$ 에서도 부갑상선의 병변으로 확인되었 다. 당뇨 등의 기저 질환은 없었으나 약 20년 전 타 병원에서 옆구리의 지방덩어리로 수술받은 적이 있으며, 가족력상 언니 가 타 병원에서 갑상선 암으로 수술받았고 이후 췌장암으로 사 망하였다. 신체 검진상 특이소견은 없었으나 말초혈액검사에 서 혈청 칼슘 $10.7 \mathrm{mg} / \mathrm{dL}$ (정상 8.6 10.2), 인 $2.1 \mathrm{mg} / \mathrm{dL}$ (정상 2.7 4.5), 알부민 $4.3 \mathrm{~g} / \mathrm{dL}$ (정상 3.5 5.2), 알칼리인산분해효소 $137 \mathrm{IU} / \mathrm{L}$ (정상 35 104), 혈액요소질소 $6.8 \mathrm{mg} / \mathrm{dL}$ (정상 6.0 20), 크레아티닌 $0.5 \mathrm{mg} / \mathrm{dL}$ (정상 0.5 0.9)로 미세한 고칼슘혈 증과 저인산혈증이 있었고 부갑상선호르몬은 $280.1 \mathrm{pg} / \mathrm{mL}$ (정 상 14 72)로 정상치의 4배 가량 증가되어 있었다.

경부 초음파에서 갑상선 내에는 임상적으로 의미 없는 작은 낭성 병변들이 있었고, 갑상선 주변으로는 4개의 부갑상선이 모두 커져 있었으며, 좌측 하 부갑상선은 $26 \times 12 \times 11 \mathrm{~mm}$, 좌 측 상 부갑상선은 $13 \times 8 \times 4 \mathrm{~mm}$, 우측 하 부갑상선은 $30 \times 13$ $\times 11 \mathrm{~mm}$, 우측 상 부갑상선은 $10 \times 6 \times 3 \mathrm{~mm}$ 로 우측 하 부갑 상선이 가장 컸다(Fig. 1). ${ }^{99 \mathrm{~m}} \mathrm{Tc}$ sestamibi 스캔의 지연영상에 서 4개의 부갑상선에서 지연된 섭취가 보였으며 우측 하 부갑 상선 부위의 섭취가 가장 강하게 보였다(Fig. 2). 골밀도 검사 에서 양측 대퇴부의 워드 삼각부위(Ward's triangle)에 각각 T-score가 -3.1, 3.5로 저하되어 있었으며, L1 2 spine에서도 -2.5로 감소되어 있었다. 양전자방출 단층촬영(positron emission tomography-computed tomography)에서 췌장두부에 SUV; 3.6의 병변이 발견되어(Fig. 3) 확인을 위해 복부 전산화 단층촬영(abdomen $\mathrm{CT}$ )을 시행하였는데 췌장의 종물 외에도

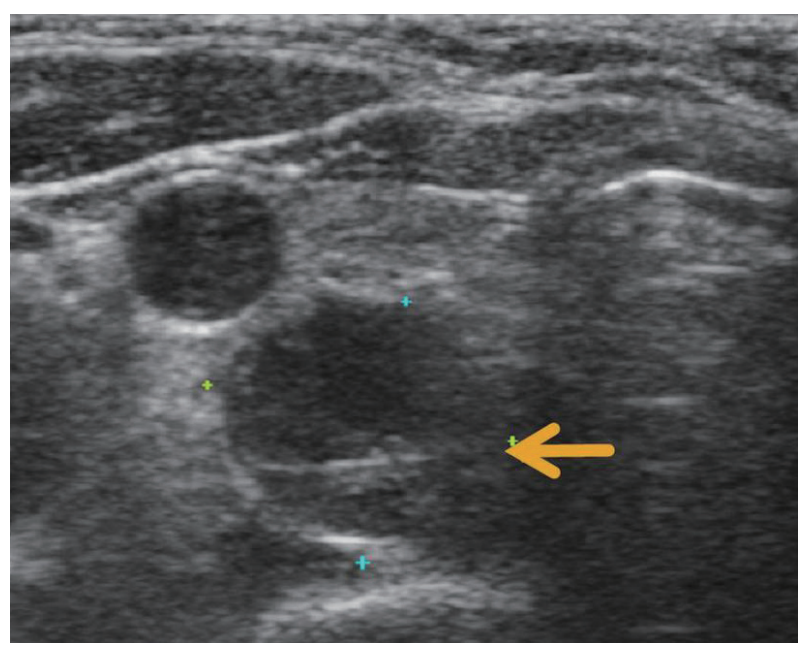

Fig. 1. Thyroid ultrasonography shows $30 \times 13 \times 11 \mathrm{~mm}$ sized right inferior parathyroid gland.
우측 부신에 $19 \mathrm{~mm}$ 가량의 결절이 발견되었다(Fig. 4).

호르몬 선별검사에서는 프로락틴 $102 \mathrm{ng} / \mathrm{mL}$ (정상 3.6 18.9) 이었고 그 외 난포자극호르몬, 갑상선자극호르몬, 성장호르몬, 부신피질자극호르몬, 혈청 가스트린이나 췌장의 기능평가를 위해 시행한 공복혈당, 인슐린, $\mathrm{C}-$ 펩티드, 부신의 기능평가 위 해 시행한 24시간 소변 코르티솔, 소변 메타네프린, 혈장레닌 활성도, 알도스테론 등도 정상이었다. 따라서 고프로락틴혈증 외에 특이하게 상승되어 있는 호르몬 수치는 없었으며, 부신 및 췌장의 기능도 정상인 것으로 보아 부신과 췌장의 병변은 비기능성 병변으로 생각되었다. 고프로락틴혈증에 대한 추가

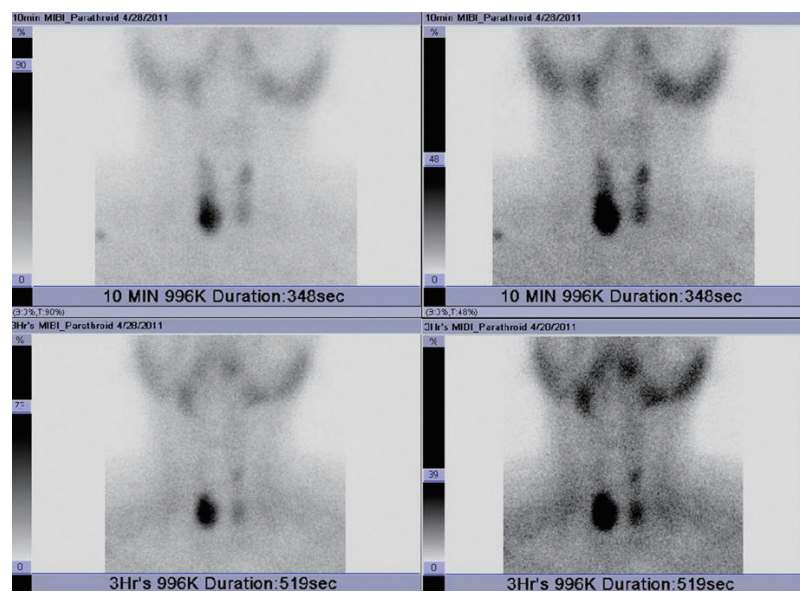

Fig. 2. ${ }^{99 m}$ Tc Sestamibi scan shows delayed uptake on 4 parathyroid glands.

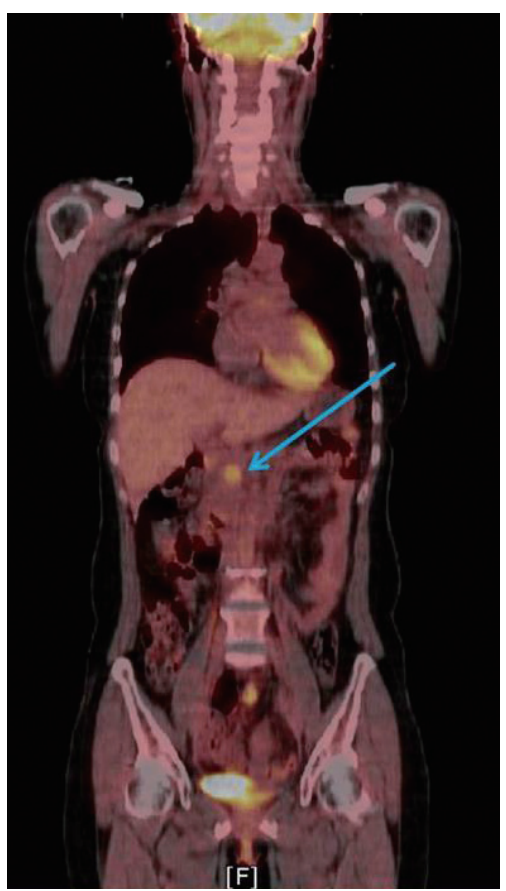

Fig. 3. Coronal view of PET-CT scan shows increased uptake on pancreas head (arrow, SUV; 3.6). PET-CT: positron emission tomography-computed tomography, SUV: standardized uptake value. 
검사를 위해 터키안 자기공명영상(sella MRI)을 시행하였고 뇌하수체 전엽에 작은 병변이 있어 뇌하수체미세선종으로 보 였다(Fig. 5).

치료 계획은 뇌하수체 선종에 대해서는 크기가 작고 증상이 없으므로 일단 내분비내과에서 추적관찰 하기로 하였고 부갑 상선과 췌장, 부신 병변에 대해서는 간담도 외과와 협진 하에 수술하기로 하였다. 먼저 이비인후과에서 부갑상선 전절제술 을 시행하였다(Fig. 6). 4개의 부갑상선에서 시행한 동결절편 검사상 모두 부갑상선 병변으로 확인되어, 가장 작은 우측의 상 부갑상선은 좌측의 상완요골근에 이식하였다(Fig. 7). 4개

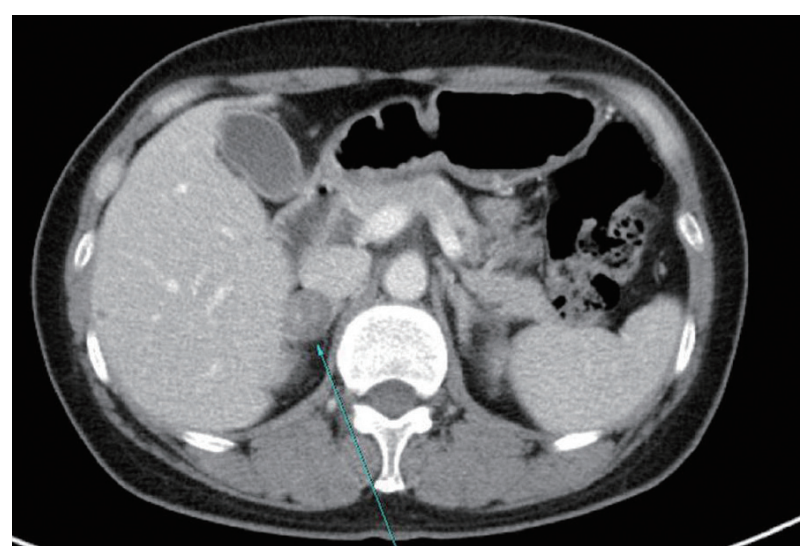

Fig. 4. Axial view of abdomen CT shows $19 \mathrm{~mm}$ sized, well-circumscribed, round and low attenuating nodule in right adrenal gland (arrow). CT: computed tomography.

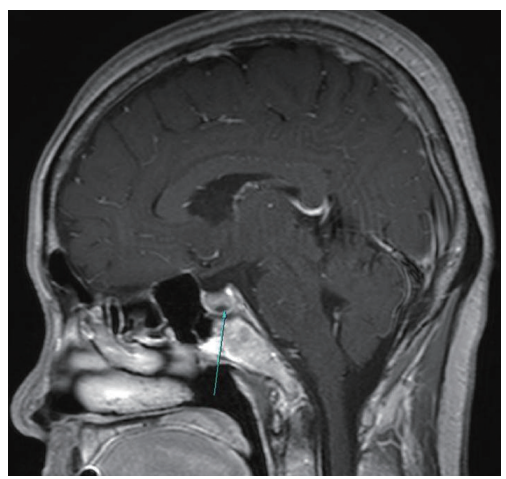

Fig. 5. Sagittal view of T1 enhanced sella MRI shows focal thickening in the anterior pituitary gland (arrow). MRI: magnetic resonance image.
의 부갑상선을 모두 제거 후 5 분 뒤에 시행한 혈청 부갑상선호 르몬 수치는 $47.9 \mathrm{pg} / \mathrm{mL}$ 로 급격히 감소하였고, 이후 10 분, 15 분에 연속으로 부갑상선호르몬을 채취하였다(Table 1). 이어 서 간담도 외과에서 췌장과 부신 수술을 위해 개복하였으며, 췌장의 종물은 십이지장의 일부와 총담관에 유착되어 있어 위 유문 보존 췌십이지장절제술(pylorus-preserving pancreatoduodenectomy) 및 담낭절제술, 우측 부신절제술을 시행하 였다. 모든 수술이 끝난 후 다시 시행한 부갑상선호르몬 수치 는 $2.5 \mathrm{pg} / \mathrm{mL}$ 이하로 검출되지 않았으며, 수술 후 혈청 칼 슘은 $6.6 \mathrm{mg} / \mathrm{dL}$ 로 저칼슘혈증을 보여 수술 후 부갑상선기능 저하증에 대하여 초기에 calcium gluconate 정맥주사와 경구 약으로 비타민 D 제제인 칼시트리올 그리고 탄산칼슘으로 조 절하였으며 이후 경구약으로 조절되어 수술 후 3주째 퇴원하 여 경구 제제 복용 중이다. 그 밖에 췌장 절제 후 인슐린 감소

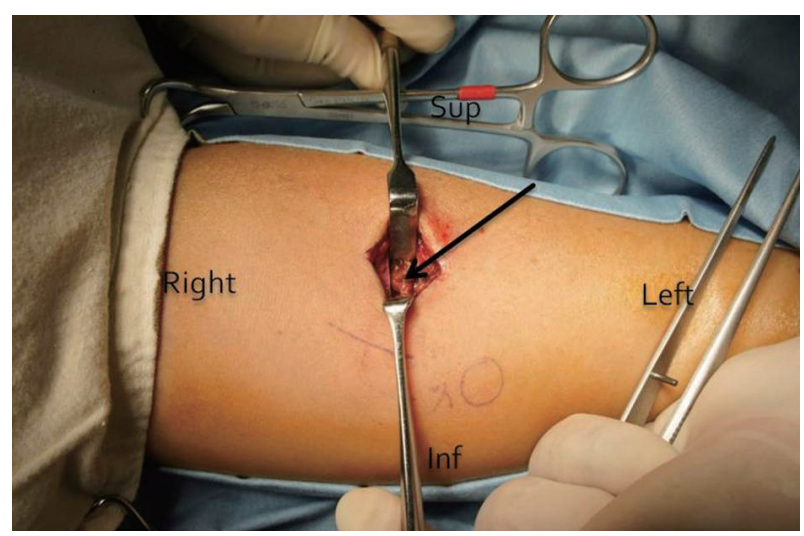

Fig. 7. Auto-grafted right superior parathyroid gland in left brachioradialis muscle of left forearm (arrow).

Table 1. Serial serum intact parathyroid hormone after parathyroid excision

\begin{tabular}{lc}
\hline \multicolumn{1}{c}{ Time } & $\begin{array}{c}\text { Intact PTH } \\
(\mathrm{pg} / \mathrm{mL})\end{array}$ \\
\hline Preoperative sampling & 284 \\
Intraoperative sampling-5 minutes after excision & 47.9 \\
Intraoperative sampling-10 minutes after excision & 33.7 \\
Intraoperative sampling-15 minutes after excision & 17.3 \\
Postoperative sampling-6 hours after excision & $<2.5$ \\
\hline
\end{tabular}

PTH: parathyroid hormone
Fig. 6. Operative findings during surgery. Right inferior parathyroid gland (arrow), trachea (arrow head), recurrent laryngeal nerve (stella)(A). Left inferior parathyroid gland (arrow), retracted thyroid gland (arrow head)(B).
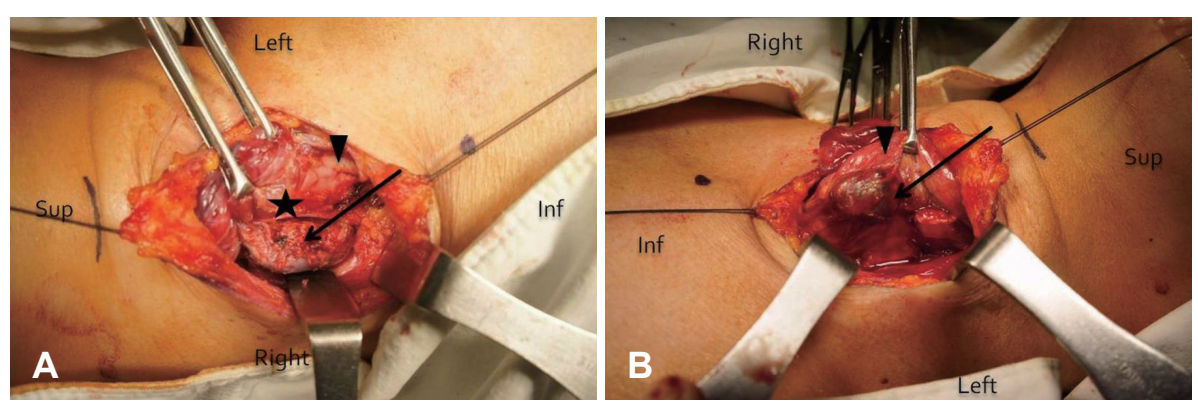

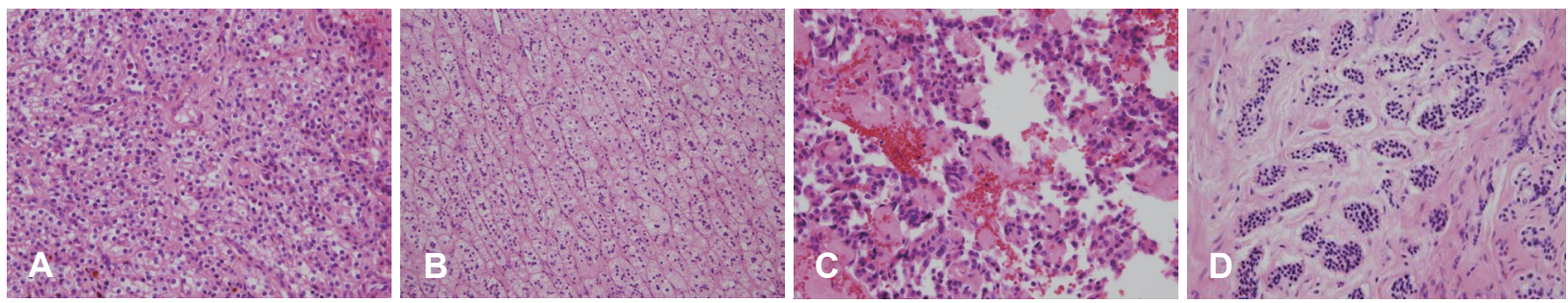

Fig. 8. Histologic features of each specimen. Parathyroid hyperplasia is composed of enlarged chief cells with large amount of cytoplasm (H\&E stain, original magnification $\times 400)(A)$. Adrenal cortical adenoma shows close intermingling of clear cells $(H \& E$ stain, $\times 400)(B)$. Regularly arranged atypical cells with mitosis are visible in well differentiated endocrine carcinoma of pancreas $(H \& E$ stain, $\times 400)(C)$. A small nodular proliferation of cells closely involve gall bladder mucosa. A lesion with this appearance is diagnosed as a carcinoid tumorlet only if it measures less than $0.5 \mathrm{~cm}(\mathrm{H} \& \mathrm{E}$ stain, $\times 400)(D)$.

로 인한 당뇨가 발생하여 현재까지 인슐린 주사로 혈당 조절 하며 내분비내과 추적관찰 중에 있다. 수술 후 외래에서 시행 한 칼슘치는 $7.5 \mathrm{mg} / \mathrm{dL}$ 였고, 부갑상선호르몬 수치는 수술 후 한달 가량은 $2.5 \mathrm{pg} / \mathrm{mL}$ 이하로 검출되지 않았으나 수술 후 40 일경에 $3.3 \mathrm{pg} / \mathrm{mL}, 70$ 일경에 $4.4 \mathrm{pg} / \mathrm{mL}$ 로 검출되기 시작하여 칼시트리올을 감량하였다.

병리검사에서 부갑상선들은 모두 과증식을 보였고, 부신 종 물은 피질 선종으로 진단되었다. 담낭에서는 유암 소종양(carcinoid tumorlet)이 발견되었으며, 췌장의 병변은 분화도가 좋 은 내분비 암종(endocrine carcinoma)으로 췌장 주변부의 제 거된 림프절 4 개 중 1 개에서 전이성 암이 관찰되었으며, 절제 면은 깨끗하였다(Fig. 8). 유전자 검사에서 종양억제 유전자인 menin 단백질을 생성하는 11q13에서의 여러 MEN mutation 들 중 9번 엑손에서의 c.1243C >T 변이가 발견되어 MEN 1으 로 최종 확진되었다.

\section{고 찰}

$\mathrm{MEN} 1$ 은 부갑상선, 장-췌장 내분비선, 뇌하수체 중 2기관 이상에서 과증식, 선종 혹은 암종 등의 증식성 병변이 있는 경 우를 일컫는 일종의 증후군으로, 부신 피질 종양, 지방종, 갈색 세포종, 갑상선종, 유암종 등이 발현될 경우 비전형적 MEN 1 으로 진단된다.,2) 본 증례는 부신 피질 선종이 있고, 20년 전 옆 구리의 지방 덩어리 수술을 받은 과거력이 있는 것으로 보아 지 방종이 동반되었을 가능성이 있어 비전형적 MEN 1으로 생각 된다. MEN 1은 상염색체 우성으로 유전되는데 실제로는 산 발적으로 발생하는 경우가 많으며, 일차성 부갑상선 기능항진 증이 $90 \%$ 이상에서 가장 많이 동반된다. ${ }^{1.3}$ 유전자 검사는 DNA 배열을 이용한 연관 분석법으로 시행한다. 현재까지 MEN 유 전자 변이는 약 400 개 가량이 발견되었는데 이 중 9번 엑손에 서의 c.784-9G>A, c.1378C > T 그리고 최근에 발견된 c.1243C $>\mathrm{T}$ 등이 그것이다. MEN 1 유전자는 종양억제 유전자로서 11 번 염색체 장완의 13번 띠(11q13)에 위치하며 61개의 아미노산
으로 이루어진 핵단백질인 menin을 전사하는데, 이는 세포 의 성장 주기를 조절하고, 이 menin이 결여되면 다발성 종양 이 발생하는 것으로 알려져 있다. ${ }^{1,25)}$ 그 외에 췌장의 병변은 $30 ~ 37 \%$ 로 문헌마다 보고가 다양하고, 뇌하수체의 병변도 18 42\%로 다양하게 보고된다.4, 본 증례에서 가족에 대한 유 전자 연구를 진행한 것은 아니지만 언니가 갑상선암으로 수술 을 받았고, 췌장암으로 사망한 것을 보아 가족력도 있을 것 으로 보인다.

뇌하수체의 병변은 프로락틴분비종의 경우 내과적 치료가 우선으로 증상이 있을 경우 Bromocriptine이나 Cabergoline 등을 사용하며 내과적 치료로 교정이 안 될 경우 수술을 시행 한다. 췌장 병변의 경우 가스트린종을 제외하고는 수술이 권장 되는데 그 이유는 췌장의 기능성 병변인 경우 인슐린, 글루카 곤 등을 분비하여 심각한 합병증이 발현될 가능성이 있고 비 기능성 종양이라 하더라도 환자의 나이가 많을 경우 본 증례 처럼 악성 종양인 경우가 있기 때문이다.) 유암종은 드물게 발 생하는데 주로 흥선이나 기관지, 위 등에 생기며 흥선에 유암 종이 생길 경우 골전이가 생길 수 있고, 5 년 생존율이 $10 \%$ 정 도로 악성 종양만큼 예후가 나쁘다. ${ }^{2.5}$ 본 증례에서는 담낭에 서 유암종이 발견되었는데 병변 크기가 매우 작은 소종양(tumorlet)으로 예후와 별 상관은 없으나 담낭에서 유암종이 발 생한 MEN 1이라는 점에서 극히 드문 경우이다. 앞서 언급한 대로 일차성 부갑상선기능항진증은 MEN 1 의 가장 흔한 발 현인데, 바꿔 말하면 MEN 1에서 부갑상선만 단독으로 병변 이 있는 경우도 많다는 뜻이다. 따라서 부갑상선의 다발성 과 증식증이 의심되면 부갑상선에 대한 검사 뿐만 아니라 $\mathrm{MEN}$ 에 준하여 전반적인 선별검사를 시행할 필요가 있다.

무증상의 일차성 부갑상선 기능 항진증의 수술적 적응에 대 한 2008년도 미국 국립 보건원 가이드라인에 따르면, 혈청 칼 슘이 정상 상한치보다 $1 \mathrm{mg} / \mathrm{dL}$ 이상일 때, 사구체여과율(glomerular filtration rate)이 $60 \mathrm{~mL} / \mathrm{min}$ 이하일 때, 골밀도 검사 에서 T-score가 - 2.5 미만인 부위가 감지되거나 골절에 취약 한 임상 소견이 보일 때, 나이가 50 세 이하일 때 중에서 한 가지 
이상을 만족할 때 수술적 치료를 권장한다. ${ }^{4)}$ 본 증례에서는 나 이가 48세이며 T-score가 -2.5 미만인 부위가 두 군데로 수 술적 적응증에 해당되었다.

수술 방법으로는 수술 중에 모든 부갑상선을 확인한 후에 동결절편 검사로 선종을 확인하여 제거하는 고전적 방법 외에 최근에는 술 전에 정확하게 병변이 있는 부갑상선의 위치를 파 악해 해당 부위에만 절개를 하여 제거하는 최소접근 부갑상 선절제술이 있는데 주로 단발성 부갑상선 선종에 사용되는 술식이다. ${ }^{4}$ 본 증례와 같이 다발성 과증식이 의심되는 경우에 는 부갑상선 아전절제술이나 전절제술이 적합한데 아전절제 술은 부갑상선 중 한 개 혹은 한 개의 일부인 $50 \mathrm{mg}$ 정도를 남 기고 나머지를 다 제거하는 방법으로 수술 후 영구적인 부갑 상선기능저하증이 $1 \%$ 이하에 불과해 기능을 보존하는 데 유리한 술식이지만, 재수술시 반회후두신경의 손상이 올 가 능성이 있다. ${ }^{4,78}$ 반면에 본 증례에서 시행한 전절제술은 모든 부갑상선을 제거한 후 가장 작고 정상적으로 보이는 부갑상선 한 개 혹은 일부인 60 80 mg 정도를 흥쇄유돌근이나 상완 요골근에 이식한다. 향후 이식한 조직이 과증식이나 선종으 로 변할 경우 다시 절제술을 시행해야 하므로 간단하게 국소 마취로 절제술을 시행할 수 있게 본 증례처럼 목보다는 전완 부인 상완요골근에 이식하는 것이 더 추천된다. 이식된 조직 이 정상적으로 부갑상선호르몬을 분비하는 기능을 하기까지 는 평균적으로 5 개월 가량이 필요하며, ${ }^{910)}$ 이때까지는 칼시트 리올 같은 비타민 제제와 칼슘 제제를 복용하면서 혈청 칼슘 과 부갑상선호르몬을 추적관찰 해야 한다. 부갑상선 전 절제 술을 시행할 때 흥선 내의 이소성 부갑상선이 있는 경우를 고 려하여 흥선도 함께 제거하는 것이 좋다는 보고도 있다. ${ }^{11)}$

\section{REFERENCES}

1) Hubbard JG, Sebag F, Maweja S, Henry JF. Primary hyperparathyroidism in MEN 1--how radical should surgery be? Langenbecks Arch Surg 2002;386(8):553-7.

2) Choi YS, Bai YS, Ku BJ, Jo YS, Kim YK, Ro HK, et al. A case of multiple endocrine neoplasia Type I with atypical clinical course. J Korean Endocr Soc 2008;23(4):266-71.

3) VanderWalde LH, Haigh PI. Surgical approach to the patient with familial hyperparathyroidism. Curr Treat Options Oncol 2006;7(4):32633.

4) PC Chen, SM Lai, YL Chen, CY Huang, KT Chen, Li CC. Multiple endocrine neoplasia type 1 with familial hyperparathyroidism - A case report. Formos J Endocrin Metab 2010;1(5):1-5.

5) Wilkinson S, Teh BT, Davey KR, McArdle JP, Young M, Shepherd JJ. Cause of death in multiple endocrine neoplasia type 1. Arch Surg 1993;128(6):683-90.

6) Vergès B, Boureille F, Goudet P, Murat A, Beckers A, Sassolas G, et al. Pituitary disease in MEN type 1 (MEN1): data from the FranceBelgium MEN1 multicenter study. J Clin Endocrinol Metab 2002; 87(2):457-65.

7) Tonelli F, Marcucci T, Fratini G, Tommasi MS, Falchetti A, Brandi ML. Is total parathyroidectomy the treatment of choice for hyperparathyroidism in multiple endocrine neoplasia type 1? Ann Surg 2007;246(6):1075-82.

8) Lambert LA, Shapiro SE, Lee JE, Perrier ND, Truong M, Wallace MJ, et al. Surgical treatment of hyperparathyroidism in patients with multiple endocrine neoplasia type 1. Arch Surg 2005;140(4):374-82.

9) Gourgiotis S, Moustafellos P, Stratopoulos C, Vougas V, Drakopou$\operatorname{los} \mathrm{S}$, Hadjiyannakis E. Total parathyroidectomy with autotransplantation in patients with renal hyperparathyroidism: indications and surgical approach. Hormones (Athens) 2006;5(4):270-5.

10) Elaraj DM, Skarulis MC, Libutti SK, Norton JA, Bartlett DL, Pingpank JF, et al. Results of initial operation for hyperparathyroidism in patients with multiple endocrine neoplasia type 1. Surgery 2003;134 (6):858-64; discussion 864-5.

11) Szabo E, Hellman P, Lundgren E, Carling T, Rastad J. Parathyroidectomy in familial hypercalcemia with clinical characteristics of primary hyperparathyroidism and familial hypocalciuric hypercalcemia. Surgery 2002;131(3):257-63. 